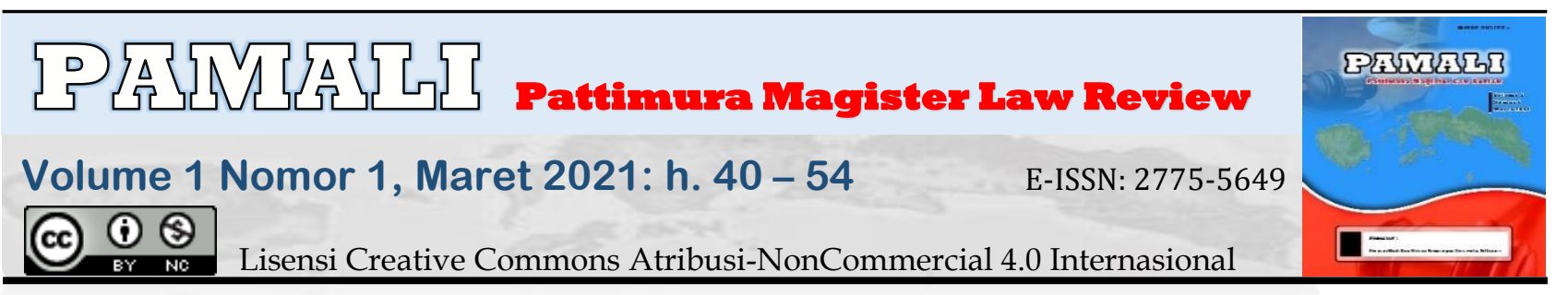

\title{
Hak Atas Tanah Pada Kawasan Konservasi
}

\section{Orias Reizal de Rooy ${ }^{1}$, Hendrik Salmon ${ }^{2}$, Reny Heronia Nendissa ${ }^{3}$}

1,2,3Fakultas Hukum Universitas Pattimura, Ambon, Indonesia.

@ : reizal2705@gmail.com

doi : $x x x x x x x x x x x x x x x x$

\begin{tabular}{l}
\multicolumn{1}{c}{ Dikirim: $07 / 01 / 2021$} \\
\hline Info Artikel \\
\hline Keywords: \\
Land Rights; Conservation \\
Areas; Syncronization of \\
Regulation. \\
Konservasi; Sinkronisasi \\
Peraturan. \\
Hata Kunci: \\
Kas Tanah; Kawasan
\end{tabular}

\begin{tabular}{ll} 
Direvisi: $19 / 02 / 2021$ & Dipublikasi: \\
\hline Abstract &
\end{tabular}

Introduction: Regulation of the land control and land use on conservation areas, especially in coastal and coastal areas refers to the agrarian regulation in general, both for the benefit of the government and the public interest. The public interest is related to the rights that the State can give to its people for certain objects. Concerning the rights of the people, the state constitution guarantees the existence of the basic rights of the people, not only to the rights to land but also to other basic rights that are indeed held by the people and must be protected by the State.

Purposes of the Research: Analyze the status of land rights in conservation areas and the legal consequences of land rights in conservation areas.

Methods of the Research: The research methods used in this article is Normative Research, which is to examines and identify laws and regulations as well as legal concepts, especially about Land Rights on Conservation Areas to be the subject of study in finding the answers to the issues above.

Results of the Research: The nature of the law which is always open and dynamic following the dynamics of changing community needs is expected to be able to answer the need for legal certainty itself through synchronization and harmonization of laws and regulations that explicitly regulate control and use of land in conservation areas that can guarantee certainty of community rights in the area. the coast.

Abstrak
Latar Belakang: Pengaturan terhadap penguasaan dan penggunaan
tanah yang ada pada kawasan konservasi khususnya di kawasan pantai
dan pesisir mengacu kepada pengaturan penguasaan dan penggunaan
tanah pada umumnya, baik untuk kepentingan pemerintah maupun
kepentingan rakyat. Kepentingan rakyat berkaitan dengan hak-hak yang
dapat diberikan oleh Negara kepada rakyatnya atas obyek tertentu.
Menyangkut hak-hak rakyat tersebut, konstitusi negara menjamin
adanya hak-hak dasar rakyat, tidak hanya terhadap hak-hak atas tanah
tetapi juga terhadap hak-hak dasar lainnya yang memang diemban oleh
rakyat dan wajib dilindungi oleh negara.
Tujuan Penelitian: Menganalisis status hak atas tanah pada kawasan
konservasi dan akibat hukum hak atas tanah pada kawasan konservasi
Metode Penelitian: Jenis penelitian yang digunakan yakni Penelitian
Yuridis Normatif atau metode penelitian hukum kepustakaan yaitu
melakukan inventarisasi dan identifikasi peraturan perundang-
undangan serta konsep-konsep hukum khususnya tentang Hak Atas
Tanah Pada Kawasan Konservasi untuk menjadi bahan kajian dalam
menemukan jawaban atas isu hukum yang diteli.


Hasil Penelitian: Sifat hukum yang selalu terbuka dan dinamis mengikuti dinamika perubahan kebutuhan masyarakat diharapkan dapat menjawab kebutuhan akan kepastian hukum itu sendiri melalui sinkronisasi dan harmonisasi perundang-undangan dan peraturan yang secara eksplisit mengatur tentang penguasaan dan penggunaan tanah pada kawasan konservasi yang dapat menjamin kepastian hak masyarakat di wilayah pesisir.

\section{Pendahuluan}

Indonesia merupakan negara yang memiliki laut dan pulau yang begitu luas dan karena itu tidak salah jika Indonesia dijuluki sebagai Negara Kepulauan. Indonesia sebagai negara kepulauan adalah salah satu negara yang memiliki kepulauan terbesar dan terbanyak di dunia yang terdiri atas 17.508 pulau dengan garis pantai sepanjang $81.000 \mathrm{~km}$ dan luas sekitar 3,1 juta $\mathrm{km}^{2}\left(0,3\right.$ juta $\mathrm{km}^{2}$ perairan teritorial dan $2,8 \mathrm{~km}^{2}$ perairan nusantara) atau $62 \%$ dari luas teritorialnya ${ }^{1}$. Sumber daya alam yang ada di wilayah Negara Kesatuan Republik Indonesia (selanjutnya disingkat NKRI) harus dimanfaatkan dengan bijaksana dan ditujukan untuk sebesar-besarnya kemakmuran rakyat,sesuai dengan amanat Pasal 33 Ayat (3) Undang-Undang Dasar Negara Republik Indonesia Tahun 1945 (selanjutnya disingkat UUD NRI Tahun 1945) yakni "Bumi dan air dan kekayaan alam yang terkandung di dalamnya dikuasai oleh negara dan dipergunakan untuk sebesar-besarnya kemakmuran rakyat." Penggunaan bumi, air dan kekayaan alam untuk sebesar-besar kemakmuran rakyat tersebut menunjukkan bahwa tujuan pemanfaatannya semata-mata untuk mensejahterakan rakyat sekaligus dengan memperhatikan aspek keadilan yang ditunjukkan dari kata "sebesarbesarnya", artinya hasil dari penggunaan dan pemanfaatan bumi, air dan kekayaan alam tersebut bukan untuk perseorangan atau kelompok tertentu tetapi untuk rakyat banyak ${ }^{2}$.

Pembahasan mengenai agraria pada mulanya hanya tertuju pada masalah mengenai tanah sebagai permukaan bumi. Tanah meliputi permukaan bumi yang ada di daratan dan permukaan bumi yang berada di bawah air, termasuk air laut ${ }^{3}$. Legalisasi aset juga menguatkan klaim atas tanah dan pemusatan tanah pada segelintir orang atau negara ${ }^{4}$, Undang-Undang Nomor 5 Tahun 1960 tentang Peraturan Dasar Pokok-Pokok Agraria (selanjutnya disingkat UUPA) pada Pasal 19 Ayat (1) dikemukakan bahwa untuk menjamin kepastian hukum oleh pemerintah diadakan pendaftaran tanah di seluruh wilayah Republik Indonesia menurut ketentuan yang diatur dengan Peraturan Pemerintah. Sumber UUPA ini lahir dari Pasal 33 Ayat (3) UUD NRI Tahun 1945. Pada Pasal 2 Ayat (2) UUPA dikemukakan bahwa: "Hak menguasai dari Negara termaksud dalam Ayat (1) pasal ini memberi wewenang untuk:

a) mengatur dan menyelenggarakan peruntukan, penggunaan, persediaan dan pemeliharaan bumi, air dan ruang angkasa tersebut;

b) menentukan dan mengatur hubungan-hubungan hukum antara orang-orang dengan bumi, air dan ruang angkasa;

c) menentukan dan mengatur hubungan-hubungan hukum antara orang-orang dan perbuatan-perbuatan hukum yang mengenai bumi, air dan ruang angkasa."

1 Rokhmin et.al Dahuri, Pengelolaan Sumber Daya Wilayah Pesisir Dan Lautan Secara Terpadu (Jakarta: Pradnya Paramita, 1996), h. 1.

2 Dahuri. h. 151

3 Boedi Harsono, Hukum Agraria Indonesia, Sejarah Pembentukan Undang-Undang Pokok Agraria, Isi Dan Pelaksanaannya (Jakarta: Djambatan, 2007), h. 6-7.

4 Ronald Saija et al., "Status Kepemilikan Hak Atas Tanah Adat Marga Dalam Kebijakan Penataan Aset Reforma Agraria Di Kabupaten Maluku Tenggara," SASI 26, no. 1 (2020): 99-110, https://doi.org/10.47268/sasi.v26i1.246, h. 103. 
Tujuan hak menguasai oleh negara atas sumber daya alam khususnya tanah ialah keadilan sosial dan sebesar-besarnya kemakmuran rakyat ${ }^{5}$. Berdasarkan konsep Pasal 2 ayat (2) UUPA tersebut, pengertian "dikuasai" oleh negara bukan berarti dimiliki, melainkan hak yang memberi kewenangan pada negara untuk menguasai hal tersebut di atas. Kemudian, dalam Pasal 14 ayat (1) UUPA mengatur bahwa dalam rangka penerapan paham sosialisme di Indonesia, pemerintah membuat suatu rencana umum mengenai persediaan, peruntukan, dan penggunaan bumi, air, dan ruang angkasa serta kekayaan alam yang terkandung di dalamnya. Wewenang tersebut dengan kata lain adalah wewenang untuk melakukan penataan ruang. Dalam melakukan penataan ruang tersebut, maka wajib memperhatikan asas-asas pengelolaan lingkungan hidup dan asas-asas penataan ruang serta asas-asas lain yang bersangkut paut dengan hal tersebut yang terdapat dalam aturan perundang-undangan lainnya. Dengan berlakunya Undang-Undang Nomor 32 Tahun 2004 tentang Pemerintahan Daerah dengan terakhir diganti dengan Undang-Undang Nomor 23 Tahun 2014 tentang Pemerintahan Daerah (selanjutnya disingkat UU No. 23 Tahun 2014) dimana tiap-tiap daerah memiliki kewenangan penuh atas daerahnya sendiri, maka tiap-tiap kepala daerah mempunyai hak untuk kemudian melakukan penataan ruang ${ }^{6}$.

Kebutuhan akan tanah tidak hanya dirasakan oleh masyarakat di perkotaan, tetapi juga masyarakat yang tinggal di pulau-pulau kecil. Masyarakat yang tinggal di pulau-pulau kecil yang berpenghuni dan memiliki akses yang cukup mudah dari pusat pemerintahan daerah memiliki laju pertumbuhan penduduk yang cukup tinggi yang mengakibatkan kebutuhan mereka akan tanah juga semakin tinggi sedangkan tanah yang tersedia sangat terbatas dan telah digunakan untuk membangun rumah dan bangunan-bangunan lainnya, sehingga mereka berusaha mencari solusi untuk memenuhi kebutuhan mereka akan tanah ${ }^{7}$. Dalam suatu wilayah pesisir terdapat satu atau lebih lingkungan dan sumber daya pesisir. Lingkungan pesisir dapat bersifat alam ataupun buatan. Lingkungan yang bersifat alami yang terdapat di wilayah pesisir antara lain terumbu karang, hutan mangroves, padang lamun, pantai berpasir, formasi pes-caprea, formasi baringtonia, laguna dan delta. Sedangkan lingkungan yang bersifat buatan yang terdapat di wilayah pesisir antara lain tambak, sawah pasang surut, kawasan pariwisata, kawasan industri, kawasan agroindustri dan kawasan pemukiman. Perencanaan dan pengelolaan wilayah pesisir secara sektoral biasanya berkaitan dengan hanya satu macam pemanfaatan sumber daya atau ruang pesisir oleh satu instansi pemerintah untuk memenuhi tujuan tertentu, seperti perikanan tangkap, tambak, pariwisata, pelabuhan, pemukiman atau industri minyak dan gas. Pengelolaan semacam ini dapat menimbulkan konflik kepentingan antar sektor yang berkepentingan yang melakukan aktivitas pembangunan pada wilayah pesisir. ${ }^{8}$

Secara kasat mata, pemanfaatan ruang di pesisir dan pantai makin tidak terkendali dan terkesan ada pembiaran oleh aparatur yang berwenang walau hal itu jelas-jelas melanggar ketentuan hukum yang berlaku. Pengaturan terhadap penguasaan dan penggunaan tanah yang ada di kawasan pantai dan pesisir mengacu kepada pengaturan penguasaan dan penggunaan tanah pada umumnya, baik untuk kepentingan pemerintah maupun kepentingan rakyat. Kepentingan

\footnotetext{
${ }^{5}$ Fengky Kotalewala, Adonia Ivone Laturette, and Novyta Uktolseja, "Penyelesaian Sengketa Dalam Pengadaan Tanah Bagi Pembangunan Jalan Untuk Kepentingan Umum," SASI 26, no. 3 (2020): 415-433, https://doi.org/10.47268/sasi.v26i3.397, h. 416.

${ }^{6}$ Muhammad Ilham Arisaputra, "Penguasaan Tanah Pantai Dan Wilayah Pesisir Di Indonesia," Perspektif Hukum 15, no. 1 (2015): 27-44, https:// doi.org/10.30649/phj.v15i1.22. h, 29

7 Yona Yonanda Soly and Yuwono Prianto, "Kesadaran Hukum Masyarakat Atas Penetapan Batas Penguasaan Tanah/Ruang Di Wilayah Pesisir Dan Pantai," Era Hukum 15, no. 1 (2017): 150-63, https://doi.org/10.24912/era\%20hukum.v15i1.669. h, 152.

8 Arisaputra, "Penguasaan Tanah Pantai Dan Wilayah Pesisir Di Indonesia." h, 28.
} 
rakyat berkaitan dengan hak-hak yang dapat diberikan oleh Negara kepada rakyatnya atas obyek tertentu. Menyangkut hak-hak rakyat tersebut, konstitusi negara menjamin adanya hak-hak dasar rakyat, tidak hanya terhadap hak-hak atas tanah tetapi juga terhadap hak-hak dasar lainnya yang memang diemban oleh rakyat dan wajib dilindungi oleh negara ${ }^{9}$.

Pada kawasan pantai juga terdapat kawasan konservasi, yang mana kawasan konservasi ini berguna bagi kelangsungan hidup masyarakat kedepan. Salah satu tujuan dari penetapan kawasan konservasi yakni melindungi habitat-habitat kritis, mempertahankan, dan meningkatkan kualitas sumberdaya, melindungi keanekaragaman hayati, dan melindungi proses-proses ekologi. Ketika kelestarian sumberdaya alam tercapai dan terjadi keseimbangan ekosistem maka dapat mendukung peningkatan kesejahteraan masyarakat dan mutu kehidupan manusia. Penguasaan tanah di wilayah pesisir diperbolehkan menurut perundang-undangan yang berlaku dimulai dengan lahirnya Undang-undang Nomor 27 Tahun 2007 tentang Pengelolaan Wilayah Pesisir dan PulauPulau Kecil (selanjutnya disingkat UU No. 27 Tahun 2007) yang pada perkembangannya diubah dengan Undang-undang Nomor 1 Tahun 2014 tentang Perubahan Atas Undang-undang Nomor 27 Tahun 2007 tentang Wilayah Pesisir dan Pulau-Pulau Kecil (selanjutnya disingkat UU No. 1 Tahun 2014) lebih memberikan jaminan kepastian hukum bagi orang-orang yang hidup di wilayah pesisir dan pantai. Tidak berbeda dengan penguasaan tanah di wilayah daratan (di luar wilayah pesisir), penguasaan tanah di wilayah pesisir juga sering mengalami masalah ${ }^{10}$. Sehubungan dengan hal tersebut, muncul suatu persoalan terhadap tanah dipesisir pantai yang merupakan kawasan konservasi. UU No. 1 Tahun 2014 menggunakan Pengelolaan Wilayah Pesisir dan Pulau-Pulau Kecil sebagai suatu pengoordinasian, perencanaan, pemanfaatan, pengawasan, dan pengendalian sumber daya pesisir dan pulau-pulau kecil yang dilakukan oleh Pemerintah Daerah, antarsektor, antara ekosistem darat dan laut, serta antar ilmu pengetahuan dan manajemen untuk meningkatkan kesejahteraan rakyat.

Pada Pasal 5 Ayat (1) Peraturan Menteri Agraria dan Tata Ruang/Kepala Badan Pertanahan Nasional Nomor 17 Tahun 2016 tentang Penataan Pertanahan di Wilayah Pesisir dan Pulau-Pulau Kecil (selanjutnya disingkat Permen ATR/Kepala BPN No. 17 Tahun 2016) mengatur sebagai berikut:

"Pemberian Hak Atas Tanah pada pantai sebagaimana dimaksud dalam Pasal 4 huruf a, hanya dapat diberikan untuk bangunan yang harus ada di Wilayah Pesisir pantai, antara lain:

a) bangunan yang digunakan untuk pertahanan dan keamanan;

b) pelabuhan atau dermaga;

c) tower pernjaga keselamatan pengunjung pantai;

d) tempat tinggal masyarakat adat atau anggota masyarakat yang secara turun-temurun sudah bertempat tinggal ditempat tersebut; dan/atau

e) pembangkit tenaga listrik."

Sejalan dengan itu, dalam Pasal 62 Peraturan Daerah Provinsi Maluku Nomor 1 Tahun 2018 tentang Rencana Zonasi Wilayah Pesisir dan Pulau - Pulau Kecil Provinsi Maluku Tahun 2018-2038 (selanjutnya disingkat Perda Provinsi Maluku No.1 Tahun 2018) menyatakan bahwa:

1) Setiap orang yang melakukan pemanfaatan ruang dari sebagian perairan pesisir dan pemanfaatan sebagian pulau-pulau kecil secara menetap wajib memiliki Izin Lokasi.

\footnotetext{
9 Soly and Prianto, “Kesadaran Hukum Masyarakat Atas Penetapan Batas Penguasaan Tanah/Ruang Di Wilayah Pesisir Dan Pantai." h, 152-153

10 Soly and Prianto. h, 153.
} 
2) Izin Lokasi sebagaimana dimaksud pada ayat (1) menjadi dasar pemberian Izin Pengelolaan.

3) Izin sebagaimana dimaksud pada ayat (1) diberikan berdasarkan RZWP-3-K.

4) Pemberian izin sebagaimana dimaksud pada ayat (1) wajib mempertimbangkan kelestarian ekosistem pesisir dan pulau-pulau kecil, ruang penghidupan dan akses kepada nelayan kecil, nelayan tradisional, pembudidaya ikan kecil, dan petambak garam kecil, kepentingan nasional, dan hak lintas damai bagi kapal asing.

5) Izin Lokasi sebagaimana dimaksud pada ayat (1), diberikan kepada:

a) orang perseorangan Warga Negara Indonesia;

b) korporasi yang didirikan berdasarkan Hukum Indonesia; dan

c) koperasi yang dibentuk oleh masyarakat.

Sementara dalam Pasal 1 angka 13 Perda Provinsi Maluku No.1 Tahun 2018 menyatakan "Perairan Pesisir adalah laut yang berbatasan dengan daratan meliputi perairan sejauh 12 (dua belas) mil laut diukur dari garis pantai, perairan yang menghubungkan pantai dan pulau-pulau, estuari, teluk, perairan dangkal, rawa payau, dan laguna."

Permasalahannya kini terkait dengan tanah-tanah hak milik masyarakat yang terletak di wilayah pesisir yang merupakan kawasan konservasi, bolehkah terus diakui sebagai hak milik. Fenomena di masyarakat terdapat hak milik pada kawasan konservasi mangrove, keberadaan hutan mangrove yang selama ini telah banyak memberikan manfaat itu, nyatanya telah banyak dibabat habis oleh masyarakat sekitar baik untuk permukiman dan pertambakan, sementara kawasan konservasi disepanjang pantai harus tetap dipelihara dan tidak dapat dimilik sebagai hak milik masyarakat.

\section{Metode Penelitian}

Tulisan ini menerapkan metode penelitian hukum normatif, dengan menggunakan pendekatan perundang-undangan (Statute Approach) guna menjelaskan aspek perundangundangan yang berisikan suatu objek tertentu kemudian dipadukan dengan pendekatan konseptual (Conceptual Approach) yang lebih mengarahkan kajian teoritik tentang pandangan ahli berdasarkan hasil-hasil penelitian maupun argumentasi pemikiran berdasarkan kebenaran ilmu tertentu, serta digunakan pula pendekatan kasus (Case Approach) untuk mempertegas kajian teoritik dan mendukung analisis pembahasan. Teknik penelusuran bahan hukum menggunakan teknik studi kepustakaan, asas-asas, pandangan-pandangan, doktrin-doktrin serta isi kaidah hukum, serta analisis kajian menggunakan deskriptif analitis.

\section{Hasil dan Pembahasan}

\subsection{Status Hak Atas Tanah Pada Kawasan Konservasi}

UUPA tidak mengatur ihwal tanahnya, melainkan soal hak atas permukaan bumi saja. Jadi, tidak termasuk seluruh bumi, air dan kekayaan alam yang terkandung di dalamnya. Tanah yang dimaksud dalam UUPA tidak sama dengan tanah yang dimaksud dalam KUH Perdata sebagai benda tak bergerak, tetapi tanah dalam UUPA memiliki asas yang sangat spesifik dan merupakan kultur budaya bangsa Indonesia. Dalam UUPA terdapat unsur komunalistik religious artinya ketentuan hukum Indonesia melihat bahwa tanah itu adalah milik bersama yang diberikan oleh sang pencipta guna kesejahteraan masyarakat, berarti Indonesia mengatur prinsip Negara kesejahteraan. Sebagai Negara kesejahteraan, Negara Indonesia mengikuti asas bahwa peraturan yang lebih rendah tidak boleh bertentangan atau menyimpang dari peraturan yang lebih tinggi tingkatannya. Karena itu Negara memiliki tugas dan tanggung jawab khusus yaitu memberikan keadilan dalam penguasaan dan pemilikan hak atas tanah sesuai dengan falsafah Pancasila. 
Pengelolaan kawasan budidaya pantai tidak dapat dipisahkan dari status fungsi dan kepemilikan lahan pada kawasan tersebut. Pemberian hak atas tanah, baik yang dikuasai secara perorangan maupun yang dikuasai secara adat untuk lahan-lahan daratan yang tidak dipengaruhi pasang surut air laut lebih mudah diselesaikan, karena sudah diatur oleh UUPA dan peraturan perundang-undangan lainnya. Pengaturan mengenai pemanfaatan wilayah pesisir dan pulau-pulau kecil di Indonesia diatur dengan UU No. 1 Tahun 2014, serta tidak terlepas pula dari UUPA. Lahirnya UU No. 1 Tahun 2014 patut diberikan apresiasi positif karena hal ini menandakan adanya niat baik dari semua pihak, terutama legislatif dan eksekutif untuk memperhatikan kawasan pesisir dan pulau-pulau kecil sebagai potensi unggulan yang selama ini termarjinalkan. UU No. 1 Tahun 2014 diharapkan menjadi payung hukum bagi semua stakeholder yang memanfaatkan kawasan perairan pesisir dan pulau-pulau kecil agar terhindar dari konflik pemanfaatan yang berkepanjangan.

Pemanfaatan perairan pesisir diberikan dalam bentuk Hak Pengusahaan Perairan Pesisir (selanjutnya disingkat HP3), yakni hak atas bagian-bagian tertentu dari perairan pesisir untuk usaha kelautan dan perikanan, serta usaha lain yang terkait dengan pemanfaatan Sumber Daya Pesisir dan Pulau-Pulau Kecil yang mencakup atas permukaan laut dan kolom air sampai dengan permukaan dasar laut pada batas keluasan tertentu. HP3 yang dimaksud meliputi pengusahaan atas permukaan laut dan kolom air sampai dengan permukaan dasar laut. HP3 diberikan dalam luasan dan waktu tertentu dan pemberian HP3 yang dimaksud wajib mempertimbangkan kepentingan kelestarian ekosistem pesisir dan pulau-pulau kecil, masyarakat adat, dan kepentingan nasional serta hak lintas damai bagi kapal asing. HP3 dapat diberikan kepada orang perseorangan warga negara Indonesia, badan hukum yang didirikan berdasarkan hukum Indonesia, atau masyarakat adat.

Pengelolaan wilayah pesisir tidak dapat dipisahkan dari status fungsi dan kepemilikan tanah pada kawasan tersebut. Pemberian hak atas tanah, baik yang dikuasai secara perorangan maupun yang dikuasai secara adat untuk lahan-lahan daratan yang tidak dipengaruhi pasang surut air laut lebih mudah diselesaikan, karena sudah diatur oleh UUPA dan peraturan perundang-undangan lainnya. Masalah lain yang sangat menonjol adalah daratan-daratan di kawasan pantai tersebut bergerak secara labil dan tak terduga. Pergeseran daratan ini dapat diakibatkan oleh adanya tanah longsor atau adanya tanah timbul akibat sedimentasi. Dalam usaha memanfaatkan tanah timbul ada perbedaan perbedaan pendapat. Ada tanah yang sudah dimanfaatkan ketika belum lagi berbentuk tanah, melainkan baru sebagai genangan air yang dangkal. Ada pula sebidang tanah timbul yang sudah dimanfaatkan, ketika sifat tanahnya masih belum pantas lagi diolah untuk menjadi tanah pertanian, karena kadar garam tanahnya masih tinggi. Dalam pertumbuhan tanah timbul, okupasi lahan oleh masyarakat belum tentu menunggu sampai benar-benar ada wujud tanah, ada pula yang merupakan wilayah konservasi mangrove Begitu tanah itu muncul kemudian dimulai pengolahannya menjadi tanah pertanian yang baik, okupasi masyarakat di atas tanah itu biasanya sudah mantap. Lahan di kawasan pantai yang tidak dibebani hak milik, dikuasai oleh Negara dan digunakan sesuai peruntukan/fungsinya untuk kemakmuran rakyat.

Sebagai contoh, pada bulan Desember 2019 salah satu Komunitas Pencinta lingkungan di Maluku melakukan penanaman mangrove pada kawasan pesisir pantai di lateri, namun sebelum dilakukan penanaman mangrove beberapa masyarakat justru mengklaim tanah yang akan ditanami mangrove sebagai kepemilikan tanah keluarga mereka. Kasus lain yang ditemukan pada kawasan Poka Kota Ambon yang juga merupakan kawasan konservasi mangrove namun tetap diberikan ijin usaha untuk dibangun beberapa usaha disitu. Hal yang sama pun terjadi pada kawasan mall ACC passo, di daerah ACC dahulunya banyak sekali tanaman mangrove disitu namun pada akhirnya juga di tebang dan tetap diberikan izin pada tanah yang merupakan kawasan konservasi. 
Termasuk dalam kategori "milik bersama" adalah pembagian hak milik atas sumber daya alam sehingga beberapa pemilik mempunyai hak yang sama untuk menggunakan sumber daya tersebut. Kepemilikan dalam arti ini hanya sebatas untuk menggunakan, tidak termasuk hak untuk mengalihkannya. Ahli waris pemilik bersama akan memiliki secara bersamasama hanya karena keanggotaannya pada kelompok (suku, desa, dan sebagainya). Adanya kepemilikan bersama tentunya tidak menafikkan keberadaan kepemilikan pribadi karena kepemilikan pribadi merupakan hak alamiah/kodrati. Hak milik adalah hak alamiah dari setiap individu berdasarkan prinsip keadilan. Hubungan pemerintah dalam pengaturan kembali hak-hak tersebut dapat dilakukan sepanjang ada konsesi terhadap hak individu tersebut. Dengan demikian, tindakan pemerintah untuk melindungi hak milik hanyalah sepanjang hak-hak untuk hidup dan kemerdekaan. Tanah di wilayah pantai pada umumnya telah tempati oleh masyarakat dalam jangka waktu yang lama dan bahkan ada yang telah dihuni atau bermukim di wilayah tersebut secara turun temurun. Penguasaan secara turun temurun tersebut bersangkut paut dengan penguasaan wilayah pesisir oleh masyarakat adat yang kemudian diakui dalam undang-undang.

Penataan ruang wilayah pesisir dan laut relatif lebih dinamis dibandingkan dengan penataan ruang wilayah daratan. Dari ketiga aspek yang mempengaruhi penataan ruang, yaitu aspek fisik, sosial dan ekonomi, ketiganya relatif lebih dinamis pada penataan ruang wilayah pesisir. Aspek fisik pada penataan ruang wilayah daratan hampir tidak berubah selama berlakunya rencana tata ruang, kecuali jika terjadi bencana alam yang merubah secara drastis rupa bumi wilayah perencanaan. Sebaliknya penataan ruang pada wilayah pesisir, perubahan aspek fisik harus diperhatikan secara khusus, karena wilayah pesisir merupakan bentang alam yang senantiasa berubah akibat intensifnya gaya-gaya di daratan dan di lautan. Di samping akibat gaya-gaya yang bersifat alamiah tersebut, wilayah pesisir dapat pula berubah akibat perbuatan manusia, proses reklamasi dan agunisasi merupakan dua contoh yang mulai banyak terjadi di Indonesia.

Dilihat dari aspek ekonomi, wilayah pesisir juga mengakibatkan perubahan yang sangat cepat pada nilai atau opportunity cost dari lahan pesisir. Kebutuhan pengembangan pelabuhan akibat membengkaknya arus perdagangan, kebutuhan lahan untuk pengembangan Water Front City akibat bertambahnya jumlah penduduk yang berpendapatan menengah ke atas yang menuntut adanya lokasi pemukiman yang lebih berkualitas, pengembangan tambak akibat kenaikan permintaan ikan/udang di pasar dunia, eksploitasi lahan pesisir menjadi tambang galian $\mathrm{C}$ akibat berbagai kepentingan dalam kebijakan peningkatan pendapatan, merupakan empat contoh klasik dari dinamika perekonomian yang memiliki dampak yang cukup besar terhadap penataan ruang wilayah pesisir.

Peta Pola Ruang Kota Ambon Tahun 2011-2031 yang menggambarkan daerah kawasan lindung, dapat dilihat rencana tata ruang yang ditujukan untuk Kawasan Pantai Berhutan Bakau (Desa Poka, Kelurahan Lateri, dan Desa Passo). Namun pada kenyataannya banyak hak atas tanah yang dimiliki masyarakat serta bangunan mal. Kawasan pesisir dari lateri hingga passo, tergambar jelas masih terdapat kepemilikan hak milik pada wilayah konservasi yang jelas berada pada pesisir pantai. Pada permasalahan ini, pada status tanah dikawasan konservasi lebih jelas dilihat jelas juga dalam Pasal 27 Peraturan Daerah Provinsi Maluku Nomor 10 Tahun 2013 tentang pengelolaan Wilayah Pesisir Dan Pulau-Pulau Kecil perlu dipertegas agar pengelolahannya tanah pada kawasan konservasi tidak banyak penggunaan lainnya di dalam kawasan konservasi karena pengelolaan kawasan konservasi merupakan kewenangan Negara dalam hal ini Pemerintah Daerah. Meskipun diatas tanah dikawasan pesisir diberikan hak Milik, Hak Guna Bangunan, Hak Guna Usaha maupun hak Pakai namun hal ini menjadi tugas pemerintah untuk menciptakan produk hukum yang harus dipertegas mengenai kepemilikan status secara tegas dalam peraturan daerah. 


\subsection{Akibat Hukum Terhadap Status Tanah Hak Milik Atas Kawasan Konservasi}

Kekayaan sumber daya pesisir dikuasai oleh negara untuk dikelola sedemikian rupa untuk mewujudkan kesejahteraan masyarakat, memberikan manfaat bagi generasi sekarang tanpa mengorbankan kebutuhan generasi yang akan datang. Secara umum, banyak masyarakat yang sudah bermukim di wilayah pesisir dan bahkan sudah ada pula yang memiliki hak atas tanah di wilayah pesisir. Hal ini kemudian berdampak pada perubahan ekosistem pesisir karena masyarakat yang bermukim di wilayah tersebut melakukan eksploitasi terhadap sumber daya pesisir. Namun, selain berdampak negatif, ada pula yang berdampak positif, yakni makin terpeliharanya ekosistem pesisir karena mereka yang bermukim di wilayah tersebut berpandangan bahwa itulah potensi hidup mereka.

Sebelum diperbarui menjadi Undang-Undang Nomor 23 Tahun 2014 Tentang Pemerintahan Daerah, Undang-Undang Nomor 32 Tahun 2004 mengatur mengenai kewenangan daerah untuk mengelola sumber daya di wilayah laut yang meliputi:

a) eksplorasi, eksploitasi, konservasi, dan pengelolaan kekayaan laut;

b) pengaturan administratif;

c) pengaturan tata ruang;

d) penegakan hukum terhadap peraturan yang dikeluarkan oleh daerah atau yang dilimpahkan kewenangannya oleh Pemerintah;

e) ikut serta dalam pemeliharaan keamanan; dan

f) ikut serta dalam pertahanan kedaulatan negara.

Kewenangan untuk mengelola sumber daya di wilayah laut tersebut paling jauh 12 mil laut diukur dari garis pantai ke arah laut lepas dan/atau ke arah perairan kepulauan untuk provinsi dan 1/3 dari wilayah kewenangan provinsi untuk kabupaten/kota yaitu 0-4 mil. Setelah adanya Undang-Undang Nomor 23 Tahun 2014 tentang Pemerintahan Daerah sebagai pengganti UndangUndang Nomor 32 Tahun 2004, maka pemerintah daerah kabupaten/kota tidak lagi memiliki kewenangan untuk mengelola wilayah laut. Pemerintah daerah kabupaten hanya memiliki kewenangan di bidang perikanan tangkap dan perikanan budidaya. Undang-Undang Nomor 23 Tahun 2014 Tentang Pemerintahan Daerah mengatur mengenai pengelolaan kelautan, pesisir, dan pulau-pulau kecil yang pembagian urusannya diserahkan kepada pemerintah daerah provinsi. Urusan tersebut terkait:

a) Pengelolaan ruang laut sampai dengan 12 mil di luar minyak dan gas bumi;

b) Penerbitan izin dan pemanfaatan ruang laut di bawah 12 mil di luar minyak dan gas bumi; dan

c) Pemberdayaan masyarakat pesisir dan pulau-pulau kecil.

Konsepsi yang menjadi dasar filosofis dari pemberian izin adalah sebagai instrumen pengawasan terhadap perilaku masyarakat. Pemberian izin juga dapat diartikan dengan pembatasan terhadap potensi-potensi yang jumlahnya terbatas. Secara umum, izin diasumsikan sebagai keputusan yang bersifat menguntungkan, sehingga tidak dapat begitu saja ditarik kembali atau diubah atas kerugian yang berkepentingan ${ }^{11}$. Perizinan tidak lahir dengan sendirinya secara serta merta, namun mestinya ditopang oleh "wewenang" yang telah diberikan kepada pejabat publik (pemerintah sebagai pelaksana undang-undang). Pada akhirnya pemberian Izin oleh pemerintah kepada orang/ individu dan badan hukum dilaksanakan melalui surat keputusan atau ketetapan yang selanjutnya menjadi ranah hukum administrasi negara.

11 Philipus M Hadjon, Pengantar Hukum Perizinan (Surabaya: Yuridika, 1993), h. 9. 
UU No. 1 Tahun 2014 membentuk aturan baru untuk menggantikan HP3, yaitu Izin Lokasi dan Izin Pengelolaan. Izin Lokasi dimaksudkan untuk memberikan izin memanfaatkan ruang dari sebagian pesisir yaitu wajib mempertimbangkan kelestarian ekosistem pesisir dan pulau-pulau kecil, masyarakat, nelayan tradisional, kepentingan nasional, dan hak lintas damai bagi kapal asing dan dalam luasan dan waktu tertentu. Sedangkan izin pengelolaan dimaksudkan untuk memanfaatkan sumber daya perairan pesisir dan perairan pulau-pulau kecil untuk kegiatan produksi garam, biofarmakologi laut, bioteknologi laut, wisata bahari, dan lain-lain sebagaimana di maksud pada pasal 19 ayat (1) dan ayat (2) UU No. 1 Tahun 2014. Dengan berlakunya hak izin lokasi dan hak izin pengelolaan, maka pihak-pihak yang mendapatkan izin tersebut sesuai dengan pasal 18 Undang-Undang Nomor 1 Tahun 2014 harus merealisasikan tujuan diberikannya izin tersebut dengan jangka waktu paling lama 2 tahun sejak izin diterbitkan agar izin tersebut tidak dicabut.

Izin Lokasi adalah izin yang diberikan untuk memanfaatkan ruang dari sebagian Perairan Pesisir yang mencakup permukaan laut dan kolom air sampai dengan permukaan dasar laut pada batas keluasan tertentu dan/atau untuk memanfaatkan sebagian pulau-pulau kecil. Sementara itu, Izin Pengelolaan adalah izin yang diberikan untuk melakukan kegiatan pemanfaatan sumber daya Perairan Pesisir dan perairan pulau-pulau kecil. Dengan demikian Izin Lokasi dibutuhkan apabila seseorang ingin menggunakan ruang dari pulau ataupun dari perairan di sekitarnya. Sementara jika penggunaan ruang tersebut diikuti dengan pemanfaatan sumber daya (penambangan, penangkapan ikan, dll), Izin Lokasi tersebut harus diikuti dengan Izin Pengelolaan.

Izin Lokasi merupakan syarat mutlak bagi Izin Pengelolaan apabila seseorang ingin melakukan pemanfaatan ruang dari sebagian wilayah pesisir atau pulau-pulau kecil. Namun kewajiban untuk mempunyai Izin Lokasi ini dikecualikan dari Masyarakat Hukum Adat. Artinya suatu kelompok Masyarakat Hukum Adat dapat melakukan pemanfaatan dan pengelolaan atas suatu wilayah pesisir atau pulau-pulau kecil tertentu tanpa perlu melapor atau mendapat izin dari Pemerintah Daerah. Dalam konteks konservasi sumberdaya alam di Indonesia sering menimbulkan konflik dengan masyarakat lokal yang mendiami area konservasi, tampak bahwa mestinya konflikkonflik tersebut tidak mungkin terjadi karena masyarakat telah memiliki nilai-nilai konservasi yang haru dilindungi keanekaragaman hayati. Argumentasi konservasi di Indonesia didasari atas pertimbangan rasional yang ditujukan untuk pemanfaatan namun tidak pada pemanfaatan yang seenaknya.

Oleh karena hukum yang mengatur tentang konservasi di Indonesia agar tidak menimbulkan konflik berkepanjangan sudah seharusnya menjadi hukum yang responsif yakni dengan mengakomodasi kepentingan masyarakat berupa wilayah konservasi yang memperhatikan nilainilai masyarakat. Pengaturan konservasi berdasarkan beberapa teori diatas diperlukan beberapa tipe hukum yang sesuai dengan karakteritik masyarakat di Indonesia, dimana nilai-nilai kearifan yang berada di masyarakat dapat menuju pada pengelolahan konservasi strategis kebijakan negara terlebih bagi daerah. Daerah sebegai pemegang kendali harusnya semakin tegas dalam memutuskan sesuatu yang salah dan melanggar aturan pada wilayah konservasi.

Hal lain yang justru ditemukan adalah tumpang tindihnya kewenangan pada kawasan konservasi. Seperti diketahui, terkait kelembagaan dalam pengelolaan taman nasional yang menurut pasal 78A UU No. 1 Tahun 2014 sudah mengamanatkan bahwa kawasan konservasi di wilayah pesisir dan pulau-pulau kecil termasuk suaka alam dan kawasan pelestarian alam yang berada di wilayah pesisir dan pulau-pulau kecil dalam bentuk Taman Nasional/Taman Nasional Laut, suaka Margasatwa, dll diserahkan pengelolaannya dari Kementerian Kehutanan ke Kementerian Kelautan dan Perikanan, namun dalam prakteknya di lapangan masih dikelola oleh PHKA (KLHK); adapula konflik antara Undang-Undang Nomor 26 Tahun 2007 tentang Penataan Ruang dengan UU No.1 Tahun 2014 terkait Rencana Tata Ruang Wilayah (RTRW) dan Rencana 
Zonasi Wilayah Pesisir dan Pulau-Pulau Kecil (RZWPPK) dimana dalam Pasal 24 ayat (1) UndangUndang Nomor 26 Tahun 2007 tentang Penataan Ruang menjelaskan bahwa rencana rinci tata ruang sebagaimana dimaksud dalam Pasal 14 ayat (3) huruf b ditetapkan dengan peraturan daerah. Tata ruang wilayah yang dimaksud mencakup ruang darat, ruang laut, dan ruang udara, termasuk ruang di dalam bumi. Sementara itu Pasal 9 ayat (5) UU No. 27 tahun 2007 jo UU No. 1 Tahun 2014 Rencana Zonasi Wilayah Pesisir dan Pulau-Pulau Kecil juga ditetapkan melalui Peraturan Daerah. Jangka waktu RTRW ataupun RZWP-3-K berlaku selama 20 (dua puluh) tahun dan dapat ditinjau kembali sekurang-kurangnya 5 (lima) tahun sekali, Pasal 9 ayat (2) UU No 14 Tahun 2014 mengatur bahwa RZWP-3-K juga harus diserasikan, diselaraskan, dan diseimbangkan dengan RTRW pemerintah provinsi atau pemerintah kabupaten/kota, hal ini menegaskan bahwa keduanya seharusnya tidak perlu dibuat dengan dua format hukum yang berbeda (dua Perda). RTRW dan RZWPPK mengatur hal yang relatif sama namun pada tataran teknis harus mengeluarkan dua Peraturan Daerah yang berbeda. Meski tidak menimbulkan permasalahan hukum, namun akan menumbulkan pembebanan anggaran.

Beranjak dari situ, justru Peraturan Daerah Provinsi Maluku No.16 Tahun 2013 tentang Rencana Tata Ruang Wilayah Provinsi Maluku 2013-2033 telah ada sejak tahun 2013 serta Perda Provinsi Maluku Nomor 1 Tahun 2018 Tentang Rencana Zonasi Wilayah Pesisir Dan Pulau-Pulau Kecil Provinsi Maluku Tahun 2018-2038 namun keberadaannya justru tidak begitu membawa dampak yang signifikan. Karena daerah pesisir yang merupakan kawasan konservasi mangrove seperti telah diuraikan dalam masalah sebelumnya seyogianya tetap diberikan izin oleh pemerintah daerah, baik itu izin mendirikan bangunan maupun izin mendirikan usaha.

Penyelenggaraan pembangunan dan/atau hak pada tanah di wilayah konservasi merupakan suatu tindakan hukum yang juga dalam pelaksanaannya menimbulkan suatu akibat hukum bagi para pihak, dalam hal ini para pihak adalah pemilik tanah, pemerintah, dan masyarakat. Wujud akibat hukum dalam teori ilmu hukum dapat berupa: ${ }^{12}$

a) lahir dan berubahnya suatu keadaan hukum;

b) lahir, berubah atau lenyapnya suatu hubungan hukum antara dua atau lebih subjek hukum, apabila antar belah pihak telah melakukan suatu hak dan kewajibannya; dan

c) lahirnya sanksi apabila dilakukan suatu tindakan yang melawan hukum.

Oleh karena itu, subjek hukum dalam hal penyelenggaraan bangunan gedung akan dikenakan sanksi berupa sanksi administrasi, sanksi perintah pembongkaran dan sanksi pidana. Permasalahan pendirian bangunan di tepi pantai tentang kepemilikan kepemilikan sertipikat hak atas tanah dan banyaknya masyarakat yang telah menempati tanah kosong di tepi pantai lebih dari 20 (dua puluh) tahun lamanya. Pada permasalahan masyarakat memiliki tanah pada kawasan konservasi di lateri, masyarakat tersebut menggunakan sistem perolehan hak secara tradisional yaitu perolehan hak atas tanah secara accupatio, yakni pendudukan tanah yang belum dimiliki oleh sesorang. Teori accupatio menjadi lemah dan tidak sesuai apabila diterapkan pada kondisi saat ini, sebab karena pertumbuhan sosial masyarakat yang semakin kompleks, mendorong berkembangnya pemikiranpemikiran dan melahirkan hukum yang logis dan baru, bahwa negara adalah pemilik tanah dan tanah merupakan suatu objek kekuasaan negara ${ }^{13}$.

Selain disebabkan karena adanya perbedaan konsep hukum tradisional Indonesia dengan hukum barat yang menimbulkan dampak persoalan pertanahan di masyarakat dalam hal perolehan hak atas tanah bagi seseorang, persoalan yang juga banyak terjadi adalah masyarakat tidak begitu mementingkan perizinan mengenai pendirian bangunan yang ditempatinya, karena merasa telah

\footnotetext{
12 Hadjon. h. 293.

13 Hadjon. h, 31
} 
memiliki hak atas bangunan tersebut melalui pengusahaan secara intensif pada tanah yang dianggapnya kosong, tanpa memperhatikan bahwa mereka melakukan pembangunan dan reklamasi serta menempati tanah tersebut yang merupakan kawasan konservasi sejak dahulu. Pada zaman ini, kebutuhan akan tanah untuk dijadikan sumber penghasilan dan nilai tanah semakin meningkat sehingga setiap orang atau badan hukum dengan berbagai usaha untuk memperolehnya baik itu dengan sengketa dalam pewarisan, okupasi bahkan memiliki tanah pada areal kawasan tanpa izin dari pihak yang berwenang.

Sebelum maupun sesudah penetapan kawasan konservasi pada tanah-tanah milik masyarakat, pemerintah terlebih dahulu melakukan inventarisasi terhadap hak-hak yang berada dalam kawasan tersebut, yang bertujuan untuk menghimpun tanah-tanah yang dimiliki masyarkat terdapat di dalam kawasan konservasi yang akan ditentukan status hukumnya dan memberikan penyelesaiannya agar dalam kawasan konservasi tidak terdapat bukti kepemilikan tanah sehingga dalam kawasan konservasi tidak ditemukan lagi alas hak apapun. Dengan dilakukan langkahlangkah preventif di atas, bertujuan untuk membuktikan bahwa pada areal kawasan konservasi tidak ada lagi terdapat bukti kepemilikan hak atas tanah berupa sertifikat, surat sporadik dan SPPT pembayaran pajak, karena hal yang terpenting dari sertifikat dapat memberikan kedudukan hukum sebagai alat pembuktian kuat guna menjamin akan kepastian hukum bagi pemegangnya.

\subsection{Perlindungan Hukum Bagi Tanah di Kawasan Konservasi}

Menurut Undang-Undang Nomor 32 Tahun 2009 mengenai perubahan atas Undang-Undang Nomor 23 Tahun 1997 tentang Perlindungan dan Pengelolaan Lingkungan Hidup (selanjutnya disingkat dengan UUPLH). Pasal 1 ayat (1) memberikan pengertian bahwa "Lingkungan Hidup adalah kesatuan ruang semua benda, daya, keadaan dan makhluk hidup, termasuk manusia dan perilakunya, yang mempengaruhi kelangsungan peri kehidupan dan kesejahteraan manusia serta mahluk hidup lain." Pasal 1 ayat (2) juga mengatakan bahwa, "Perlindungan dan Pengelolaan Lingkungan Hidup adalah upaya sistematis dan terpadu yang dilakukan untuk melestarikan fungsi lingkungan hidup dan mencegah terjadinya pencemaran dan/atau kerusakan lingkungan hidup yang meliputi perencanaan, pemanfaatan, pengendalian, pemeliharaan, pengawasan dan penegakkan hukum".

Sejalan dengan itu pengelolaan kawasan pesisir dan pantai memiliki pengertian bahwa pengelolaan sumber daya alam dan jasa-jasa lingkungan pesisir melalui penilaian secara menyeluruh (comprehensive assesment), merencanakan serta mengelola segenap kegiatan pemanfaatannya guna mencapai pembangunan yang optimal dan berkelanjutan, dengan demikian keterpaduan dalam perencanaan dalam pengeloaan kawasan pesisir dan pantai mencakup 4 (empat) aspek, yaitu:

a) Keterpaduan ekologis atau wilayah, meliputi batasan wilayah perencanaan (bukan batasan administratif), kawasan pesisir sebagai dasar pengelolaan kawasan dihulunya dan keterpaduan antara ekosistem darat dan laut;

b) Keterpaduan sektoral, yaitu antara sektor-sektor pembangunan;

c) Keterpaduan disiplin ilmu, merupakan perhitungan dan pertimbanganpertimbangan akademis sebagai input kebijakan;

d) Keterpaduan stakeholder, yaitu pengelolaan yang menjadi tanggung jawab antara pemerintah dan masyarakat.

Norma agama sebagai norma dasar kehidupan manusia pada hakikatnya mengakui hak milik sebagai hak asasi yang harus dijamin, tidak adapun satu agama di dunia ini yang membolehkan seseorang merusak atau bahkan mencuri barang milik orang lain. Pengakuan juga terkandung dalam larangan melakukan praktik penipuan serta larangan terhadap semua tindakan yang 
merugikan harta benda milik orang lain ${ }^{14}$. Kepemilikan tanah oleh masyarakat merupakan sebuah hak asasi manusia yang dilindungi oleh hukum Internasional maupun hukum nasional. Dalam hukum Internasional, hak milik ini diatur dalam Deklarasi Universal Hak Asasi Manusia (DUHAM), yang mana dalam Pasal 17 ayat (1) dan ayat (2) menyebutkan bahwa:

1) Setiap orang berhak untuk memiliki harta benda baik secara pribadi maupun bersamasama dengan orang lain;

2) Tidak seorangpun dapat dirampas harta bendanya secara sewenang-wenang.

Berdasarkan ketentuan di atas, dijaminnya secara konstitusional perllindungan hak kepemilikan termasuk di dalamnya adalah hak kepemilikan tanah. Hal ini menunjukkan bahwa hak atas tanah kepemilikan merupakan salah satu hak yang paling esensial bagi manusia selain hak untuk hidup. Konsekuensinya bahwa negara, melalui institusinya, bertanggung jawab untuk melindungi, memenuhi menghormati, dan memfasilitasi masyarakat dalam mencapai dan mempertahankan hak atas kepemilikan oleh setiap orang tanpa diskriminasi.

Kawasan Konservasi sebagai benteng terakhir pelestarian sumber daya di Indonesia, tidak terlepas dari beberapa permasalahan seperti di uraikan atas. Hal ini tentu saja ironis, mengingat penunjukan maupun penetapan suatu kawasan menjadi kawasan konservasi merupakan salah satu bentuk perwujudan upaya konservasi. Suatu batasan dari konservasi sumber daya alam hayati adalah pengelolaan sumber daya alam hayati yang pemanfaatannya dilakukan secara bijaksana untuk menjamin kesinambungan persediannya dengan tetap memelihara dan meningkatkan kualitas keanekaragaman dan nilainya. Penetapan kawasan konservasi di atas tanah hak milik tidak serta merta dapat dihilangkan hak kepemilikannya atas tanah setelah status kawasan berubah menjadi hutan lindung dan juga dengan penetapan kawasan hutan lindung, sertipikat yang dipengang oleh masyarakat tidak akan memberikan kedudukan hukum sebagai alat pembuktian yang kuat guna menjamin kepastian hukum bagi pemegangnya.

Pengawasan, pembinaan dan penegakan hukum yang masih lemah telah memicu timbulnya berbagai permasalahan lingkungan. Kurangnya pengawasan dan penegakkan terhadap pelaksanaan hukum baik di tingkat bawah (masyarakat) maupun tingkat atas (pemerintah) membuat kecenderungan kerusakan lingkungan lebih parah. Hal ini dapat dilihat dari tidak adanya suatu lembaga khusus yang independen dengan otoritas penuh melakukan pengawasan dan penegakan hukum yang mengatur pengelolaan sumberdaya alam. Saat ini di Indonesia telah banyak hukum dan peraturan yang mengatur tentang pengelolaan sumberdaya pesisir dan lautan yang berkelanjutan. Namun pada kenyataannya hukum dan peraturan-peraturan tersebut banyak yang tidak diimplementasikan. Hal ini disebabkan oleh lemahnya penegakkan hukum (law enforcement), egoisme sektoral (sectoral egoism) dan lemahnya koordinasi antara sektor.

Berdasarkan peraturan sektoral tersebut, terjadi konflik kepentingan antar institusi dalam mengelola wilayah konservasi sumberdaya pesisir laut dan pulau-pulau kecil. Bahkan, seiring dengan era otonomi daerah, ada kecenderungan pemerintah daerah membuat peraturan-peraturan daerah berdasarkan kepentingannya dalam meningkatkan pendapatan asli daerah (PAD). Oleh karenanya, hal ini dikhawatirkan menimbulkan ketidakpastian hukum dalam pembangunan di wilayah pesisir laut dan pulau-pulau kecil yang dapat berujung pada kerusakan wilayah konservasi.

Paradigma bahwa masyarakat di sekitar kawasan konservasi (masyarakat lokal) merupakan ancaman bagi kelestarian kawasan konservasi tampaknya sudah tidak relevan lagi untuk diterapkan saat ini, mengingat fakta di lapangan bahwa prinsip konservasi sendiri ternyata banyak

14 Achmad Ali, Perlindungan Hak Asasi Manusia Dibidang Kepemilikan Tanah (Jakarta: Komisi Nasional Hak Asasi Manusia, 2005). h. 14-15 
diadopsi oleh kultur (budaya lokal) mereka, terutama dalam pengelolaan sumberdaya alam secara bijak. Bahkan minimnya informasi bagi masyarakat disekitar kawasan konservasi pun menjadi berbahaya dalam kehidupan sumber daya di kawasan konservasi.

Dari permasalahan diatas maka langkah-langkah yang perlu diperhatikan dalam pembangunan perlindungan dan konservasi alam adalah Community Based Conservation Management, merupakan suatu pola dalam pengembangan kawasan konservasi di Indonesia mengingat keterkaitan masyarakat sangat kuat secara historik, yaitu dengan cara sebagai berikut:

1) Pemahaman terhadap sosial budaya berkaitan dengan pola lingkungan secara tradisional perlu lebih digalakan mengingat peran serta masyarakat lokal sangat penting dalam upaya konservasi;

2) Perlunya kepekaan dalam menjaring berbagai isu pengembangan yang konkret di lapangan seperti kebutuhan akan programprogram pembangunan yang lebih cepat dapat memberikan manfaat langsung bagi peningkatan kesejahteraan masyarakat nelayan, peningkatan lingkungan hidup, dan percepatan otonomi daerah;

3) Pembuatan aturan hukum dan sanksi yang tegas bagi pengrusak dan pelanggar kebijakan tentang kawasan konservasi;

4) Perlu dipertegas RTRW bagi kawasan konservasi agar kawasan konservasi tetap dipelihara. Dimana pelestarian wilayah konservasi di Indonesia didasarkan untuk pemanfaatan yang mempertimbangkan kepentingan generasi;

5) Peran serta masyarakat dan para pelaku pembangunan kawasan konservasi. Pada masa sekarang cenderung terjadi pergeseran paradigma pendekatan, dari top down ke bottom up di dalam proses perencanaan tata ruang yang lebih demokratis dan akomodatif terhadap semua kepentingan. Pengalaman-pengalaman masa lalu banyak menunjukkan bahwa perencanaan yang prosedural, normatif, dan kurang mengakomodasikan kepentingan para pelaku pembangunan yang ada di dalam proses penyusunannya, menjadi kurang dapat diimplementasikan karena menghadapi berbagai kendala di lapangan. Rencanarencana seperti itu selain kurang aspiratif juga cenderung tidak legitimasi (diakui), tidak diterima, dan tidak ditaati didalam pelaksanaannya.

6) Salah satu dari banyak hal yang selama ini hampir tidak pernah diperhatikan di dalam proses penataan ruang adalah masyarakat sama sekali tidak mengetahui ataupun diberi hak untuk ikut menegosiasikan penyelesaian konfllik ataupun aspek kompensasi terhadap konsekuensi-konsekuensi biaya dampak yang ditimbulkan oleh akibat diberlakukannya rencana tata ruang pada suatu kawasan baik terhadap timbulnya dampak lingkungan fisik maupun sosial ekonomi. Oleh karena itu kiranya masih perlu dipertimbangkan perlunya keberadaan lembaga protokol penataan ruang wilayah laut, pesisir, dan pulau-pulau kecil yang bersifat operasional, independen, bekerja atas dasar profesi, serta mampu dan berkewenangan untuk memediasi konflik dan kepentingan antar para pelaku pembangunan;

7) Rencana pengembangan perlu disusun dalam satu struktur tata ruang yang terpadu antar wilayah darat dan pesisir laut yang memungkinkan bagi berlangsungnya keterkaitan fungsional antar keduanya. Dalam rencana ini juga ditentukan sektor-sektor unggulan (leading sectors) pengembangan dimana sektor-sektor kegiatan lain harus menyesuaikan dan mendukungnya.

Salah satu bentuk perlindungan hukum terhadap masyarakat pemegang sertipikat hak milik atas tanah dan masyarakat yang bermukim di dalam kawasan hutan lindung yaitu dengan opsi relokasi dimana pemerintah menyiapkan lokasi yang layak sebagai hunian dengan pertimbangan lahan masyarakat tersebut berada di dalam kawasan konservasi, mencegah perambahan yang 
berkelanjutan oleh masyarakat, mempertahankan fungsi hutan lindung dan kondisi topografi. Demi tercapainya keadilan diantara masyarakat dan pemerintah maka dilakukan relokasi.

Kepemilikan tanah masyarakat yang berada pada kawasan pesisir dilindungi dengan dibuktikan dengan kepemilikan masyarakat pada kawasan pesisir. Dengan ini maka pemerintah memiliki bukti yang cukup dalam merelokasi tanah pada kawasan konservasi tersebut. Sebelum mencapai hal ini, maka koordinasi antar sector terkait merupakan basis utama dalam mendukung hal dimaksud.

Dengan pembuktian kepemilikan hak masyarakat pada kawasan pesisir maka menjadi titik untuk melakukan relokasi hak milik masyarakat yang berada pada kawasan pesisir, hingga dalam hal ini hak masyarakat terlindungi dan pemerintah menata kawasan konservasi pun menjadi lebih aman. Sejalan dengan itu, penataan RTRW juga tetap dijalaskan dengan baik dan tidak menimbulkan tumpang tindih aturan satu sama lainnya.

\section{Kesimpulan}

Adanya tumpang tindih kepentingan atas tanah pada kawasan konservasi dalam hal ini kawasan lindung sehingga tidak ada kepastian hak atas tanah tersebut dikarenakan koordinasi antar instansi dalam bidang pertanahan dan juga pemerintah daerah serta instansi terkait, serta harmonisasi peraturan mengenai tanah-tanah masyarakat di atas kawasan konservasi yang peruntukan dan penggunaannya diatur oleh Negara untuk kepentingan umum yang kurang maksimal, akibatnya status hak atas tanahnya menjadi tidak jelas. Pemerintah daerah cenderung mengeluarkan peraturan-peraturan daerah terkait perizinan untuk meningkatkan pendapatan asli daerah tanpa memperhatikan Rencana Tata Ruang Wilayah yang didalamnya diatur terkait perlindungan terhadap kawasan-kawasan lindung agar tetap dilestarikan untuk generasi yang akan datang.

Hak-hak keperdataan yang dimiliki masyarakat pada kawasan konservasi masih diakui, namun Negara mengatur peruntukan, penggunaan dan pemanfaatnya agar hak-hak keperdataan itu tidak beralih secara individu sehingga merugikan kepentingan umum. Pemerintah Daerah tidak mengatur secara spesifik terkait pengaturan hak atas tanah di dalam kawasan konservasi yang ditetapkan melalui RTRW maupun RZWP3K sehingga akibat hukumnya yaitu timbul ketidak pastian penegakan hukum dan juga tumpang tindih kewenangan.

\section{Referensi}

Ali, Achmad. Perlindungan Hak Asasi Manusia Dibidang Kepemilikan Tanah. Jakarta: Komisi Nasional Hak Asasi Manusia, 2005.

Arisaputra, Muhammad Ilham. "Penguasaan Tanah Pantai Dan Wilayah Pesisir Di Indonesia." Perspektif Hukum 15, no. 1 (2015): 27-44. https:/ / doi.org/10.30649/ phj.v15i1.22.

Dahuri, Rokhmin et.al. Pengelolaan Sumber Daya Wilayah Pesisir Dan Lautan Secara Terpadu. Jakarta: Pradnya Paramita, 1996.

Hadjon, Philipus M. Pengantar Hukum Perizinan. Surabaya: Yuridika, 1993.

Harsono, Boedi. Hukum Agraria Indonesia, Sejarah Pembentukan Undang-Undang Pokok Agraria, Isi Dan Pelaksanaannya. Jakarta: Djambatan, 2007.

Kotalewala, Fengky, Adonia Ivone Laturette, and Novyta Uktolseja. "Penyelesaian Sengketa Dalam Pengadaan Tanah Bagi Pembangunan Jalan Untuk Kepentingan Umum." SASI 26, no. 3 (2020): 415-33. https:// doi.org/10.47268/sasi.v26i3.397. 
Saija, Ronald, Fransiscus X. V. R Letsoin, Rory Jeff Akyuwen, and Pieter Radjawane. "Status Kepemilikan Hak Atas Tanah Adat Marga Dalam Kebijakan Penataan Aset Reforma Agraria Di Kabupaten Maluku Tenggara." SASI 26, no. 1 (2020): 99-110. https:// doi.org/10.47268/sasi.v26i1.246.

Soly, Yona Yonanda, and Yuwono Prianto. “Kesadaran Hukum Masyarakat Atas Penetapan Batas Penguasaan Tanah/Ruang Di Wilayah Pesisir Dan Pantai." Era Hukum 15, no. 1 (2017): 15063. https://doi.org/10.24912/era\%20hukum.v15i1.669. 